\title{
Вплив фармакокорекціі на патофізіологічні особливості морфофункціональних змін нижніх сечовивідних шляхів за наявності експериментального гіперактивного сечового міхура
}

\section{О. І. Яцина 1 , Р. С. Вастьянов ${ }^{2}$, І. М. Савицька ${ }^{3}$, С. В. Вернигородський ${ }^{4}$,} О. А. Гейленко ${ }^{3}$ Ф. І. Костєв ${ }^{2}$

${ }^{1}$ Національний інститут раку, м. Київ,

${ }^{2}$ Одеський національний медичний університет,

${ }^{3}$ Національний інститут хірургії та трансплантології імені О. О. Шалімова НАМН України, м. Київ,

${ }^{4}$ Вінницький національний медичний університет імені М. І. Пирогова

\section{Impact of pharmacological correction on pathophysiological peculiarities of morpho-functional changes in lower urinary ways in experimental hyperactive bladder}

\section{O. I. Yatsyna ${ }^{1}$, R. S. Vastyanov ${ }^{2}$, I. M. Savytska ${ }^{3}$, S. V. Vernygorodskyi ${ }^{4}$, O. A. Geylenko ${ }^{3}$, F. I. Kostev}

${ }^{1}$ National Cancer Institute, Kyiv,

${ }^{2}$ Odessa National Medical University,

${ }^{3}$ Shalimov National Institute of Surgery and Transplantology, Kyiv,

${ }^{4}$ National Pirogov Memorial Medical University, Vinnytsya

\section{Реферат}

Мета. Дослідження відновних процесів у нижніх сечовивідних шляхах під впливом фармакокорекції та визначення найбільш перспективної моделі лікування експериментального гіперактивного сечового міхура (ГАСМ).

Матеріали і методи. Експериментальні дослідження проведені на 120 статевозрілих білих щурах-самицях, яким моделювали ГАСМ. Після створення моделі ГАСМ тварин розподілили на чотири групи. Тварин трьох груп, крім 4-ї, у свою чергу розподілили на три підгрупи кожну, і в кожній підгрупі застосовували фармакокорекцію в різних комбінаціях.

Гістологічні дослідження сечового міхура та уретри проводили після виведення тварин з експерименту через 14 та 28 діб. Результати. Під впливом фармакокорекції, проведеної у всіх групах тварин, знижувалась детрузорна гіперактивність сечового міхура. У групі тварин, яким застосовували спазмекс, прояви атонії були менш вираженими, ніж у групі тварин, яким вводили мірабегрон. Мірабегрон у комбінації з іншими препаратами значно знижував тонус детрузора у тварин усіх трьох підгруп. У тварин, яким вводили тестостерон та естрадіол, спостерігали менш виражені прояви атонії детрузора, ніж у тварин, у яких фоновим препаратом був мірабегрон. Тонус детрузора відновився майже до рівня фізіологічної норми у всіх підгрупах тварин, яким вводили кверцетин в комбінації з іншими препаратами.

Висновки. Спазмолітичні препарати значно знижують тонус детрузора, проте спричиняють перерозтягнення стінки сечового міхура. Найбільш вдало на гіперактивність детрузора сечового міхура впливала комбінація кверцетину зі статевими гормонами, відновлюючи фізіологічний стан органа.

Ключові слова: фармакокорекція; гіперактивний сечовий міхур; детрузор; відновні процеси; статеві гормони.

Abstract

Objective. Investigation of restorative processes in the lower urine-excreting ways under the influence of pharmacotherapy, and determination of the most perspective model of the experimental hyperactive bladder (HAB) treatment.

Materials and methods. Experimental investigations were conducted on 120 sexually mature white male rats, in which a HAB was simulated. After creation of a hyperactive bladder (HAB) the laboratory animals were divided into four groups. The laboratory animals of every one of three groups, except the fourth, were further divided into three subgroups, and in every subgroup pharmacocorrection was applied in various combinations.

Histological investigations of the bladder and urethra were conducted after exclusion of laboratory animals from the experiment in 14 and 28 days.

Results. The detrusor hyperactivity of the bladder have been lowered under the influence of pharmacotherapy, conducted in all the laboratory animals groups. In a group of laboratory animals, in which spasmex was applied, the signs of atony were less pronounced, that in group of laboratory animals, in which mirabegron was injected. Mirabegron in combination with other preparations have lowered the detrusor tone in laboratory animals of all three subgroups significantly. Less pronounced signs of the detrusor atony, than in laboratory animals, in which mirabegron served as a background preparation, were observed in laboratory animals, to which testosterone and estradiol were injected. The detrusor tone was restored almost to the physiological norm level in all subgroups of laboratory animals, to which quercetin was injected with other preparations.

Conclusion. Spasmolytic preparations reduce the detrusor tone, but cause the bladder overstretching. Combination of quercetin with і статевими hormones, restorating the organ physiological state, have affected the bladder detrusor hyperactivity most favorably.

Keywords: pharmacotherapy; hyperactive bladder; detrusor; restoration processes; sexual hormones. 
Синдром гіперактивного сечового міхура (ГАСМ) включає до 10 найпоширеніших захворювань, які значно знижують якість життя. Згідно з сучасними уявленнями про ГАСМ його розвиток є багатофакторним, однак патогенез ГАСМ залишається до кінця не з'ясованим. В останній час поряд з нейрогенною теорію виникнення ГАСМ дослідники дедалі більшої уваги надають вивченню морфологічних змін, які виникають в гладких міоцитах детрузора, та їх взаємодії з екстрацелюлярним матриксом (ЕЦМ). Саме порушення міжклітинних з'єднань як провідних шляхів вважають одним з головних механізмів виникнення ГАСМ [1]. Основними компонентами стінки сечового міхура (CM) є гладком'язові волокна, між якими розташований ЕЦМ, що складається переважно з колагену та еластину. Колаген відповідає за міцність щодо розриву і цілісності, тоді як еластин забезпечує еластичність і пружність тканин. У свою чергу структурні та функціональні зміни колагену та еластину впливають на скорочувальну активність гладких міоцитів [2].

Основою патогенезу гіперактивності СМ є підвищена збудливість міоцитів його м'язової оболонки [3]. У хворих з ГАСМ виявляють підвищену ритмічну активність детрузора - м'язової оболонки [4]. Полегшують цей стан м-холіноблокатори. Мірабегрон, який покращує резервуарну функцію СМ за рахунок стимуляції бета-3-адреноблокаторів, розташованих у його стінці, вважають більш перспективним [5, 6]. Статеві гормони, особливо в комбінації з деякими препаратами, що впливають на регенераційний потенціал клітин, підвищують активність антиоксидантної системи, стабілізують роботу клітинних структур СМ [7, 8]. Зниження детрузорної гіперактивності досягається шляхом підвищення активності процесів метаболізму в міоцитах та стабілізації їх ферментних систем, підвищення потенціалу спокою. Тому для дослідження ми підбирали комбінації препаратів, які мають не тільки спазмолітичні та регенераційні властивості, а й антиоксидантний вплив на клітинні системи.

Мета дослідження: дослідити відновні процеси в нижніх сечовивідних шляхах під впливом фармакокорекції та визначити найбільш перспективні моделі лікування експериментального ГАСМ.

\section{Матеріали і методи дослідження}

Експерименти з відтворення моделі ГАСМ були проведені на 120 статевозрілих білих лабораторних щурах-самицях масою тіла 300 г, яких розподілили на групи. Щурам 1-ї групи, яка була контрольною, внутрішньоочеревинно вводили 0,3 мл стерильного фізіологічного розчину щодобово протягом 14 діб. Тваринам 2-ї групи (дослідної) 3 метою моделювання ГАСМ один раз на добу протягом 14 діб вводили внутрішньоочеревинно 0,3 мл розчину хомвіотензину, що містив 0,45 мг резерпіну. Відтворення моделей було підтверджено проведеними нами дослідженнями (МПК А61К 9/00 Пат. на корисну модель №127670 «Спосіб моделювання гіперактивного сечового міхура». Заявлено 25.04.2018, заявка № u201804535. Опубліковано 10.08.2018, бюл.№5).

Після створення моделі ГАСМ 100 тварин розподілили на чотири групи - 3-тю, 4-ту, 5-ту та 6-ту. Тварин пер-

\begin{tabular}{|c|c|c|}
\hline Таблиця 1. & \multicolumn{2}{|c|}{$\begin{array}{l}\text { Схеми введення препаратів } \\
\text { фармакокорекції тваринам 3-6-ї груп }\end{array}$} \\
\hline Групи & Підгрупи & Препарати фармакокорекції \\
\hline \multirow{3}{*}{3} & a & Кверцетин 10 мг; тестостерон 1 мг \\
\hline & 6 & $\begin{array}{l}\text { Кверцетин } 10 \text { мг; тестостерон } 1 \text { мг; } \\
\text { естрадіол 0,2 мг }\end{array}$ \\
\hline & B & Кверцетин 10 мг; мірабегрон 8 мг \\
\hline \multirow{3}{*}{4} & a & $\begin{array}{l}\text { Мірабегрон } 8 \text { мг; тестостерон } 1 \text { мг; } \\
\text { естрадіол 0,2 мг }\end{array}$ \\
\hline & 6 & Мірабегрон 8 мг; тестостерон 1 мг \\
\hline & B & Мірабегрон 8 мг; естрадіол 0,2 мг \\
\hline \multirow{3}{*}{5} & a & $\begin{array}{l}\text { Спазмекс 0,4 мг; тестостерон } 1 \text { мг; } \\
\text { естрадіол 0,2 мг }\end{array}$ \\
\hline & 6 & Спазмекс 0,4 мг; тестостерон 1 мг \\
\hline & B & Спазмекс 0,4 мг; естрадіол 0,2 мг \\
\hline 6 & & Тестостерон 1 мг; естрадіол 0,2 мг \\
\hline
\end{tabular}

ших трьох груп після 14-добового лікування одним препаратом у свою чергу розподілили на три підгрупи, в кожній з яких здійснювали окрему фармакокорекцію (табл. 1). У цих групах для лікування застосовували: 1 мл розчину мірабегрону (Астелас Фарма Юроп Б. В.) щодня через гастральний зонд 14 і 28 діб (8 мг, 1/6 таблетки, розчиненої у 1 мл дистильованої води); квертін (ПАТ НВЦ «Борщагівський ХФЗ») щодня через гастральний зонд 14 та 28 діб, 1 мл розчину, який містив 10 мг кверцетину (1/4 таблетки, розчиненої у 1 мл дистильованої води); спазмекс (Dr. R. Pfleger GmbH) щодня 14 та 28 діб внутрішньоочеревинно 1 мл, який містив 0,4 мг троспія хлориду (1/4 таблетки, розчиненої в 10 мл фізіологічного розчину); тестостерону пропіонат (ПАТ «Фармак») щодня 14 і 28 діб внутрішньом'язово 0,05 мл готового розчину, який містив 1 мг тестостерону, та дивігель (Оріон Корпорейшн, Фінляндія) щодня 14 і 28 діб, наносячи гель на виголену ділянку спини 0,2 г, який містив 0,2 мг естрадіолу. Комбінуючи препарати, їх дози не змінювали.

Працюючи з лабораторними тваринами, дотримувалися вимог «Науково-практичних рекомендацій по утриманню лабораторних тварин і роботі з ними» ДФЦ МОЗ України (протокол № 8 від 22.06.2012 р).

Після виведення тварин з експерименту проводили морфологічне дослідження СМ та уретри. Для гістологічних досліджень у строки 14 та 28 діб тварин виводили 3 експерименту передозуванням $10 \%$ розчину тіопенталу натрію. Після чого видаляли СМ, уретру та фіксували їх у 10\% нейтральному розчині формаліну впродовж 24 год, зневоднювали у спиртах зростаючої концентрації, просвітлювали у хлороформі та ущільнювали в парафіні. Зрізи товщиною 5 - 7 мкм забарвлювали гематоксиліном та еозином, пікрофуксином за ван Гізоном та резорцин-фуксином за Вейгертом [9]. Фотодокументування гістологічних препаратів здійснювали за допомогою цифрової камери ICC50 HD світлооптичного мікроскопа Leica DM 500.

\section{Результати}

На 14-ту добу експерименту після введення резерпіну за допомогою морфологічного аналізу у тварин 2-ї групи (дослідної) встановлено виражену гіпертрофію стін- 


\begin{tabular}{|c|c|c|c|}
\hline \multirow{3}{*}{$\begin{array}{l}\text { Таблиця } 2 . \\
\text { Групи тварин }\end{array}$} & \multicolumn{3}{|c|}{ Товщина м'язового шару стінки СМ (мм) після створення моделі ГАСМ та фармакокорекці } \\
\hline & \multirow{2}{*}{ Види фармакокорекції } & \multicolumn{2}{|c|}{ Строки спостереження, доба } \\
\hline & & 14-та & 28-ма \\
\hline $\begin{array}{c}\text { 1-ша } \\
\text { (контрольна) }\end{array}$ & - & $0,41 \pm 0,013$ & $0,42 \pm 0,009$ \\
\hline $\begin{array}{c}\text { 2-га } \\
\text { (модель ГАСМ) }\end{array}$ & - & $0,97 \pm 0,05^{+}$ & $0,89 \pm 0,017^{\dagger}$ \\
\hline $3 a$ & Кверцетин, тестостерон & $0,66 \pm 0,026^{*}$ & $0,62 \pm 0,022 *$ \\
\hline 36 & Кверцетин, тестостерон, естрадіол & $0,57 \pm 0,034^{*}$ & $0,48 \pm 0,008^{*}$ \\
\hline Зв & Кверцетин, мірабегрон & $0,67 \pm 0,029 *$ & $0,66 \pm 0,026^{*}$ \\
\hline $4 a$ & Мірабегрон, тестостерон & $0,75 \pm 0,026^{*}$ & $0,67 \pm 0,032 *$ \\
\hline 46 & Мірабегрон, естрадіол & $0,62 \pm 0,028^{*}$ & $0,61 \pm 0,019 *$ \\
\hline $4 \mathrm{~B}$ & Мірабегрон, тестостерон, естрадіол & $0,56 \pm 0,022 *$ & $0,57 \pm 0,021 *$ \\
\hline $5 a$ & Спазмекс, тестостерон & $0,85 \pm 0,027^{v}$ & $0,79 \pm 0,031^{v}$ \\
\hline 56 & Спазмекс, естрадіол & $0,81 \pm 0,03^{v}$ & $0,75 \pm 0,024^{v}$ \\
\hline 5в & Спазмекс, тестостерон, естрадіол & $0,79 \pm 0,026$ & $0,68 \pm 0,015^{*}$ \\
\hline 6 & Тестостерон, естрадіол & $0,71 \pm 0,03^{*}$ & $0,63 \pm 0,022 *$ \\
\hline Примітка. & $\begin{array}{l}\text { 0,001 у порівнянні з 2-ю групою (мод } \\
\text { 0,05 у порівнянні з 2-ю групою (моде) }\end{array}$ & 1 у порівнянг & (контрольною) \\
\hline
\end{tabular}

ки СМ у порівнянні з 1-ю (контрольною) групою (р < 0,001). Гіпертрофія м'язових волокон супроводжувалася ї дегенеративними змінами з вакуолізацією цитоплазми. Товщина м'язового шару становила $(0,97 \pm 0,05)$ мм (табл. 2). Пухка сполучна тканина, яка оточувала судини, мала нерівномірний набряк та забарвлювалася пікрофуксином у блідо-рожевий колір. Колагенові волокна поступово витісняли гладкі міоцити, займаючи до третини м'язового шару. Еластичні волокна розповсюджувалися вздовж м'язових пучків та судинних стінок, більшість їх зазнавала дегенеративних змін з фрагментацією та лізисом.

Після застосування спазмексу у тварин 5-ї групи прогресували дистрофічні і дегенеративні зміни колагенових та еластичних волокон, достовірних змін у кількісному складі різних типів колагенів у порівнянні з 2-ю групою не виявлено ( $>$ > 0,05). Проте у 3-й та 4-й групах (фармакокорекція в комбінації з гормональними препаратами) достовірно зменшувались як дистрофічні зміни в гладких міоцитах, так і гіпертрофія м'язового шару в порівнянні з 2-ю групою. Аналогічні патоморфологічні зміни виявляли в уретрі.

На 28-му добу експерименту у 2-й групі після застосування резерпіну без фармакокорекції в міжклітинному матриксі інтенсивно утворювались зрілі колагенові фібрили за рахунок збільшення числа зрілих фібробластів з подальшим формуванням пучків фібрилярних волокон. Прогресували дегенеративні зміни у вигляді осередкової гомогенізації, фрагментації колагенових та еластичних волокон. Колагенові волокна розросталися переважно з боку власної пластинки, розшаровуючи м'язовий шар, при цьому фуксинофілія їх зростала, що добре було помітно у разі забарвлення пікрофуксином за ван Гізоном. У 5-й групі, тварини якої отримували спазмекс, склеротичні зміни прогресували, проте, як і у 4-й групі, тварини якої отримували мірабегрон, результати на даному етапі спостереження були достовірно кращими.

Оцінка морфофунціонального стану детрузора у тварин групи За, яким вводили кверцетин та тестостерон, показала, що через 14 діб СМ містив 1,0 мл сечі, а через 28 діб - 1,2 мл (ємність сечового міхура білого щура-самиці в нормі 0,9 - 0,95 мл), був помірно атонічний, слизова оболонка утворювала численні розгалужені складки, перехідний епітелій помірно розтягнутий, дещо потоншений. Судини мікроциркуляторного русла слизової оболонки розширені, повнокровні, судини підслизової основи також повнокровні. Тонус м'язової оболонки помірний, гладком'язові клітини без ознак патологічних змін. На 28-му добу тонус м'язової оболонки дещо знижувався, перехідний епітелій залишався потоншеним, прояви повнокров'я зменшувались. Уретра була без виражених особливостей як на 14-ту, так і на 28-му добу. Кровоносні судини слизової та підслизової оболонок помірно повнокровні, розширені, внутрішній просвіт уретри помірно розширений, довгі складки слизової оболонки займали дві третини радіуса просвіту на 14-ту добу, а на 28-му - три чверті.

У тварин групи 3б, яким вводили кверцетин, тестостерон та естрадіол, на 14-ту добу СМ містив до 1,1 мл сечі, а на 28-му - 1,0 мл. На 14-ту добу епітеліальна пластинка слизової оболонки дещо потоншувалась внаслідок помірного розтягнення. Слизова оболонка утворювала численні глибокі нерозгалужені складки, м'язова оболонка була помірно атонічна. На 28-му добу тонус м'язової оболонки майже не змінювався, в ній спостерігали вогнищеву гіпертрофію та незначну кількість сполучнотканинних волокон, які добре виявлялися у разі забарвлення за ван Гізоном (рис. 1). Уретра мала форму півмісяця, складки слизової оболонки були короткі, епітеліальна пластинка без особливостей, власна пластинка слизової оболонки на 14-ту добу була дещо ущільнена, на 28-му добу значних відмінностей ії не виявлено.

У тварин групи 3в, яким вводили кверцетин, мірабегрон, СМ був помірно атонічний, на 14-ту добу містив 1,4 мл сечі, на 28-му - 1,3 мл. Через 14 діб слизова оболонка утворювала переважно довгі розгалужені складки. Епітеліальна пластинка потоншувалась через розтяг- 


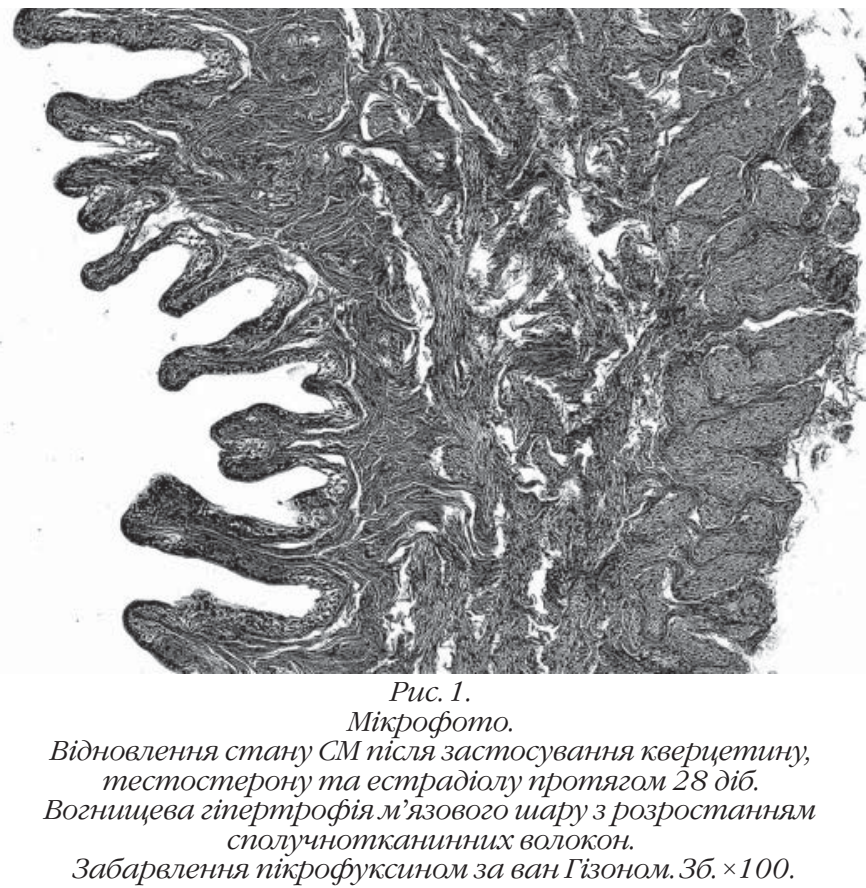

нення внаслідок більш вираженої, ніж у тварин груп За та 3б, атонії. Ці прояви зберігались до кінця експерименту. Слизова оболонка уретри без особливостей, помірно атонічна, складки ії не розгалужені, довгі. М'язова та адвентиційна оболонки не мали значних змін як на 14-ту, так і на 28-му добу.

У тварин групи 4а, яким вводили мірабегрон, тестостерон та естрадіол, СМ був розтягнутий, містив до 1,6 мл сечі на 14-ту добу та 1,8 мл - на 28-му добу. Слизова оболонка утворювала не дуже довгі, але розгалужені складки. Епітеліальна пластинка ії потоншувалась, особливо на верхівці складок, що було більш виражено на 28-му добу, коли формувались невеличкі оголені ділянки. На 14ту добу тонус міоцитів м'язової оболонки знижувався та зберігався таким на 28-му добу, адвентиційна оболонка без особливостей. Уретра не мала особливостей в обидва строки спостереження, помірно атонічна, складки слизової оболонки по всій внутрішній поверхні рівномірні, глибиною до двох третин радіуса.

У тварин групи 4б, яким вводили мірабегрон та тестостерон, СМ був сильно розтягнутий сечею, об'єм якої становив до 1,8 мл на 14-ту добу та до 2 мл на 28-му добу. Його м'язова оболонка була атонічна в обидва строки, слизова оболонка утворювала короткі та широкі складки, епітеліальна пластинка потоншувалась на 14-ту добу, на 28-му добу епітелій не тільки потоншувався, а й зазнавав значної десквамації (рис. 2), на окремих ділянках його майже не було.

На 14-ту добу в уретрі складки слизової оболонки були нерівномірно розташовані, різні за довжиною, широкі або вузькі, на 28-ту добу - рівномірно розташовані, переважно короткі. Епітеліальна пластинка потоншувалась на 14-ту добу та дещо відновлювалась на 28-му добу, власна пластинка ущільнювалась, особливо на 28-му добу. М'язова оболонка була помірно атонічна в обидва строки.

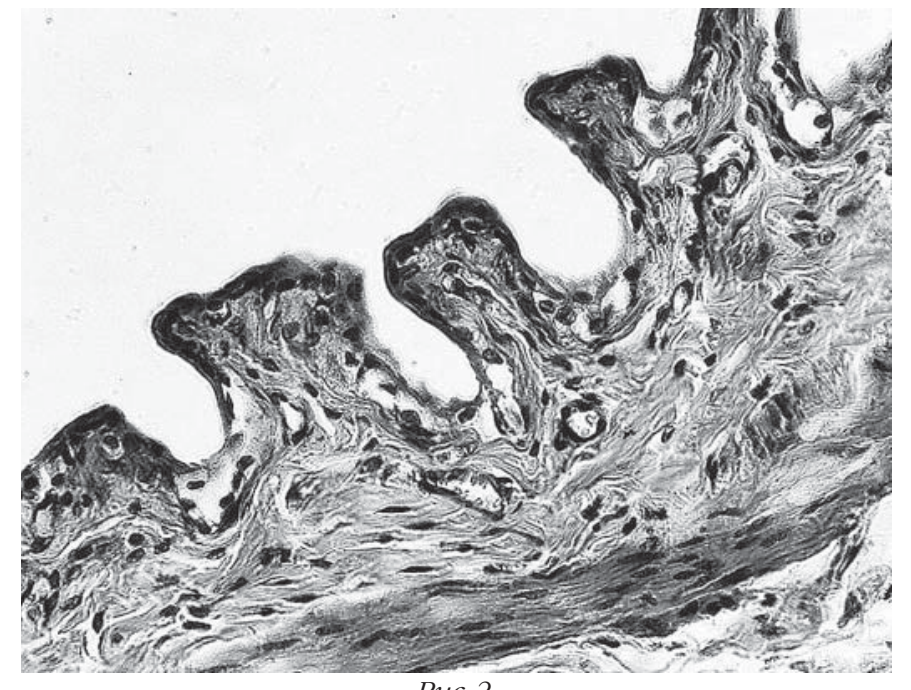

Puc. 2.

Мiкрофото.

Потоншення епітеліальної пластинки слизової оболонки СМ у разі застосування мірабегрону та тестостерону через 28 діб.

Забарвлення гематоксиліном та еозином. 3б. ×400.

У тварин групи 4в, яким вводили мірабегрон та естрадіол, СМ був помірно розтягнутий та містив до 1,3 мл сечі на 14-ту добу та до 1,6 мл на 28-му добу. Через 14 діб його слизова оболонка утворювала різні за формою та розміром недовгі складки, проте на 28-му добу вони ставали довшими та розгалужувались. Епітеліальна пластинка зазнавала гіпертрофії, особливо на 28-му добу.

На 14-ту добу уретра мала неоднорідні за формою та довжиною складки, переважно довгі та вузькі, на 28-му добу вони ставали більш короткими та розгалуженими. На 28-му добу тонус м'язового шару дещо знижувався, епітеліальна та власна пластинки слизової оболонки були інфільтровані лімфоцитами.

У тварин групи 5a, яким вводили спазмекс, тестостерон та естрадіол, СМ на 14-ту добу був розтягнутий та містив до 1,5 мл сечі, залишаючись таким до кінця експерименту. Його слизова та підслизова оболонки утворювали короткі, широкі згладжені складки, епітеліальна пластинка майже не змінювалась до кінця експерименту, візуально наближалась до інтактної. М'язова оболонка була помірно атонічна в обидва строки.

В уретрі через 14 діб складки слизової оболонки були згладжені, проте на окремих ділянках формувались поодинокі досить довгі складки (по 1 - 2 складки на згладженій поверхні). На 28-му добу уретра була розширена зі звичайними складками. Епітеліальна пластинка не мала особливостей в обидва строки.

У тварин групи 5б, яким вводили спазмекс та тестостерон, СМ містив до 1,3 мл сечі на 14-ту добу та 1,5 мл на 28му добу. На 14-ту добу складки слизової оболонки були переважно короткі, здебільшого не розгалужені, на 28-му добу кількість складок зменшувалась. У підслизовій основі кровоносні судини на 14-ту добу майже на мали особливостей, проте на 28-му добу були різко розширені, повнокровні. Розширеними були також судини гемомікро- 


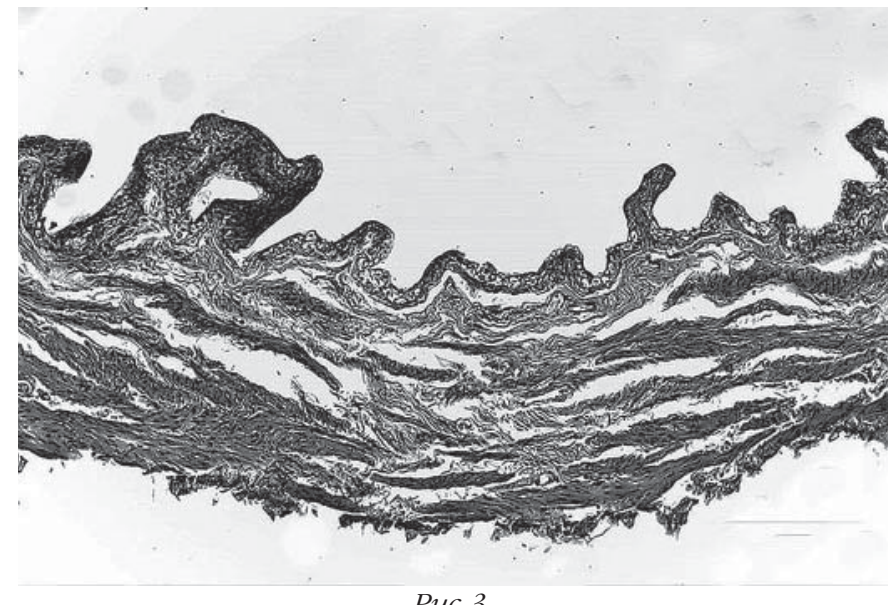

Мiкрофбото

Зменшення кількості складок слизової оболонки СМ, зниження його тонусу у разі застосування тестостерону та естрадіолу через 28 діб.

Забарвлення гематоксиліном та еозином. $36 . \times 100$

циркуляторного русла слизової оболонки. Епітеліальна пластинка на 14-ту добу була розтягнута, на 28-му добу - ще й потоншена на бічних поверхнях та вершинах, проте мала інтактну товщину на дні складок.

На 14-ту добу слизова оболонка уретри помірно атонічна, утворювала нечисленні складки. На 28-му добу просвіт уретри мав форму півмісяця, складки були поодинокі короткі, широкі. М'язова оболонка залишалась помірно атонічною, кровоносні судини розширені, повнокровні.

У тварин групи 5в, яким вводили спазмекс, естрадіол, СМ був заповнений сечею в об'ємі до 1,2 мл на 14-ту добу та до 1,4 мл на 28-му добу. На 14-ту добу його слизова оболонка утворювала недовгі, але переважно розгалужені складки, які на 28-му добу більш згладжувались. Поверхневі клітини перехідного епітелію СМ переважно сплощені. Власна пластинка слизової оболонки дещо ущільнювалась, особливо на 28-му добу. Атонія м'язової оболонки на 14-ту добу слабка, а на 28-му добу помірно виражена.

В обидва строки спостереження просвіт уретри мав неправильну форму, слизова оболонка утворювала поодинокі короткі складки, епітеліальна пластинка мала будову, як на інтактних ділянках.

У тварин групи 6, яким вводили тестостерон та естадіол, СМ містив сечі до 1,2 мл на 14-ту добу та 1,6 мл на 28-му добу, був слабо атонічний на 14-ту добу, а на 28-му добу його тонус ще зменшувався. Слизова оболонка по всій внутрішній поверхні утворювала складки, які на 28-му добу ставали більш короткими, епітеліальна пластинка потоншувалась, власна пластинка дещо ущільнювалась (рис. 3).

В обидва строки дослідження уретра мала форму півмісяця, складки ії слизової оболонки були короткі, а епітеліальна пластинка на невеличких ділянка потоншувалась, на інших - без особливостей.

\section{Обговорення}

Проведена нами фармакокорекція у всіх групах тварин знижувала детрузорну гіперактивність СМ. Проте у 5-й групі тварин, яким застосовували спазмекс в комбінації з гормональними препаратами, прояви атонії були менш вираженими, ніж у тварин 4-ї групи, яким вводили мірабегрон з гормональними препаратами, однак тонус детрузора був більш знижений, ніж у тварин 3-ї групи, яким вводили кверцетин та гормональні препарати.

Мірабегрон значно знижував тонус детрузора у тварин всіх трьох підгруп 4-ї групи. Через стійке розтягнення СМ підвищувалась десквамація його перехідного епітелію. У разі застосування мірабегрону в комбінації з естрадіолом спостерігали гіпертрофію епітеліальної пластинки слизової оболонки, в комбінації з тестостероном або тестостероном та естрадіолом, навпаки, підвищену десквамацію поверхневих клітин.

Застосування тестостерону та естрадіолу у тварин 6-ї групи приводило до менш виражених проявів атонії детрузора, ніж у тварин 4-ї групи.

Тонус детрузора відновлювався майже до рівня норми у всіх підгрупах 3-ї групи тварин, яким вводили кверцетин в комбінації з іншими препаратами. Стан детрузора, що наближався до інтактного, спостерігали у тварин групи 36 у разі використання комбінації кверцетину з тестостероном та естрадіолом.

Відомо, що збільшення експресії колагену на фоні високої експресії металопротеїназ є відображенням процесів ремоделювання (синтезу та деградаціі) пошкоджених тканин або тканин, що випробовують постійне механічне навантаження [10]. Повноцінність відновлення тканин визначається співвідношенням активності процесів біосинтезу та катаболізму компонентів ЕЦМ. Поряд зі структурною перебудовою колагенових волокон у нашому дослідженні виявлені дегенеративні зміни еластичних волокон (іх зернистий розпад, фрагментація, зменшення кількості). Все це може призводити до значної втрати еластичних властивостей досліджуваних тканин, порушуючи їх розтяжність і пошкоджуючи м'язово-еластичний каркас. На наш погляд, саме пошкодження сполучнотканинного матриксу може бути причиною рецидиву нетримання сечі. Отже, на пізніх етапах посилення фібрилогенезу зі склеротичними змінами призводить до зниження еластичності тканин та порушення мікроциркуляції стінки змодельованого ГАСМ.

\section{Висновки}

1. Спазмолітичні препарати та агоністи бета 3 -адренорецепторів спричиняли значне зниження тонусу детрузора, перерозтягнення стінки СМ. Статеві гормони (тестостерон та естрадіол) підвищували активність міоцитів детрузора СМ, не викликаючи значного зниження його тонусу.

2. Морфологічні зміни, які виникали у змодельованому нами ГАСМ, підтверджують стадійність його морфогенезу починаючи з компенсаторної гіпертрофії стінки з дегенеративними змінами гладких міоцитів, що з часом призводило до виснаження адаптаційних можливостей 3 наступною декомпенсацією та склерозом стінки СМ.

3. У групі експериментальних тварин, які отримували спазмекс та його комбінації з гормонами, не виявлено достовірної ефективності їх впливу на ГАСМ. У разі окремо- 
го застосування мірабегрону, особливо його комбінації 3 тестостероном та естрадіолом, встановлена позитивна динаміка морфологічних показників на ранніх етапах (14 діб), в той час як кверцетин та його комбінація з гормональними препаратами були більш ефективними на пізніх етапах дослідження (28-ма доба). Комбінація кверцетину зі статевими гормонами виявилась найбільш вдалою за наявності ГАСМ, вона відновлювала фізіологічний стан органа.

4. Подальше вивчення морфологічних аспектів проблеми ГАСМ дасть можливість диференційовано вибирати тактику фармакокорекції з метою підвищення ефективності відновлення детрузора з урахуванням його морфофункціонального стану.

\section{Підтвердження}

\section{Фінансування.}

Це дослідження є фрагментом планової НДР.

Фінансування за рахунок держбюджету.

Інформація про внесок кожного учасника.

Всесок кожного автора в цю роботу однаковий. Всі автори прочитали і схвалили остаточний варіант рукопису. Конфлікт інтересів.

Автори, які взяли участь в цьому дослідженні, декларуЮть відсутність конфлікту інтересів щодо цього рукопису.

Згода на публікацію

Всі автори дали згоду на публікацію цього рукопису.

\section{References}

1. Elbadawi A, Yalla CB, Resnick NM. Structural basis of geriatric voiding dysfunction. III. Detrusor overactivity. J Urol. 1993;150(5 Pt 2):166. PMID: 8411455.

2. Foditsch EE, Roider K, Patras I, Hutu I, Bauer S, Janetschek G, Zimmermann R. Structural changes of the urinary bladder afer chronic complete spinal cord injury in minipigs. Int Neurourol J. 2017;(21):12-9. http:// doi.org/10.5213/inj.1732666.333.

3. Kubota Y, Kojima Y, Shibata Y, Imura M, Sasaki S, Kohri K. Role of KIT-positive interstitial cells of Cajal in the urinary bladder and possible therapeutic target for overactive bladder Adv Urol. 2011;(11):816342. http://doi.org/10.1155/2011/816342.

4. Ljubarskaja JuO, Atduev VA. Giperaktivnyj mochevoj puzyr' Remedium Privolzh'e. 2014;(5):36-7 [In Russian].

5. Karpov EI. Lechenie giperaktivnogo mochenogo puzirja: rasshirjaem gorizonty. Medicinskij sovet. 2016;(10):140-2. http://doi.org/10.21518/2079701X-2016-10-140-142. [In Russian].

6. Khullar V, Amarenco G, Angulo JC. Efficacy and tolerability of mirabegron, a 3-adrenoreceptor agonist, in patients with overactive bladder: results from a randomized European-Australian Phase 3 Trial. Eur Urol 2013Feb;63(2):283-95. http://doi.org/10.1016/j.eururo.2012.10.016.

7. Trubnikova NN, Fedorova AA, Revjakina EG. Vliianie urovnia polovyh gormonov na aktivnost antioksidantnoj sistemy. Patologija. 2008;(2):667 [In Russian].

8. Berdicheskij VB. Giperaktivnyj mochevoj puzyr'. Medicinskaja nauka i obrazovanie Urala. 2015;(2):146-9 [In Russian].

9. Avtandilov GG. Osnovy patologoanatomicheskoj praktiki. Rukovodstvo (izdanie trete dopolnennoe). Moskva: Rossijskaja medicinskaja akademija poslediplomnogo obrazovanija; 2007. 480 p. [In Russian].

10. Vishwajit S, Fuelhase C, Badlani GH. The biochemistry of wound healing in the pelvic floor: what have we learned? Current bladder dysfunction reports. 2009 March, 4(1): 13-19. http://doi.org/10.1007/s11884009-0003-5. 